\title{
Barley varieties registered in the Slovak Republic after harvest 2018
}

\author{
Vratislav Psota ${ }^{1 *}$, Marián Svorad $^{2}$, Markéta Musilová ${ }^{1}$ \\ 1 Research Institute of Brewing and Malting, \\ Mostecká 7, CZ-614 00 Brno, Czech Republic \\ 2 Central Control and Testing Institute in Agriculture, \\ Department of Variety Testing, Topolčianska 488/29, \\ SK-956 07 Vel'ké Ripňany, Slovak Republic
}

*Corresponding author: psota@beerresearch.cz

\begin{abstract}
We present the malting quality and agronomic characters data obtained within a three-year testing of barley varieties for the registration in the Slovak Republic. After harvest 2018, new spring barley malting varieties Chimbon, Laureate and LG Aurus were registered. The extract content in dry matter in the studied varieties was high and ranged from 83.1-83.5\%. The varieties had strong proteolytic modification (Kolbach index 49.5-50.7\%). Amylolytic and cytolytic modification was at the optimal level. Wort quality was optimal (apparent final attenuation 81.5-82.2\%).
\end{abstract}

Key words: barley, variety, malting quality

\section{Introduction}

In the Slovak Republic, new barley varieties are registered under Act 597/2006 on the basis of a three-year testing. The tests for the registration of new varieties involve the monitoring of the utility value, i.e. yield and other yield characteristics, resistance to diseases, lodging and traits characterizing malt quality. The quality of malt samples was evaluated on the basis of the characteristics given in the malting quality indicator. The quality of malt samples was assessed based on the characters given in the malting quality index (Psota and Kosař, 2002).

This study evaluates the technological and agronomical quality of the spring barley malting varieties Chimbon, Laureate, and LG Aurus, which in 2018 completed the trials for the registration (Tables 1, 2, 3).

\section{Material and Methods}

The list of all barley varieties registered after harvest 2018 is given in Table 1. Information on agronomical characteristics of the varieties was obtained as part of the state varietal tests of the Slovak Republic from the testing stations of the Central Controlling and Testing Institute in Agriculture in Bratislava (CCTIA).

Malting quality of spring barley varieties was assessed based on the micromalting test and subsequent analytical analysis of malt and wort. Seed samples for the micromalting tests were delivered by the Department of Variety Testing CCTIA in Bratislava, in 2016-2018.

Grain samples of the tested varieties were collected annually from four testing stations where the standard varieties exhibited the optimal content of nitrogenous substances $(10.2-11.2 \%)$. Samples $(0.5 \mathrm{~kg})$ were malted in the micromalting plant of the KVM company (CR). The method traditionally used in the Research Institute of Brewing and Malting, which is almost identical with the MEBAK method (2011), was used for laboratory malting. Steeping was conducted in the steeping box. The temperature of both water and air was kept at $14.0^{\circ} \mathrm{C}$. Length of steeping: $1^{\text {st }}$ day -5 hours; $2^{\text {nd }}$ day -4 hours. On the third day the water content in germinating grains was adjusted to the value of $45 \%$ by steeping or spraying. Germination 
was conducted in the germination box. The temperature during germination was $14.0^{\circ} \mathrm{C}$. The total time of steeping and germination was $144 \mathrm{~h}$.

Kilning was performed on a onefloored electrically heated kiln. The total kilning time was $22 \mathrm{~h}$, prekilning at $55^{\circ} \mathrm{C}$, kilning temperature was $80{ }^{\circ} \mathrm{C}$ for 4 hours.

In the course of the tests, Malting Quality Index (nitrogenous substances in non-malted grain, extract in malt dry matter, relative extract at $45{ }^{\circ} \mathrm{C}$, Kolbach index, diastatic power, apparent final attenuation, friability, $\beta$-glucans in wort, wort clarity and haze) was determined according to the methods presented in publications of MEBAK (2011) and EBC (2010). The variety was assessed according to the malting quality index (Psota and Kosař, 2002). Wort clarity determined visually was assessed as follows: 1 = clear, 2 = weakly opalizing, 3 = opalizing, 4 = cloudy (Table 2 ).

Agricultural characters of varieties include (Table 3): - yield of grain at standard 14\% moisture content. Yield of grain and yield of grain over $2.5 \mathrm{~mm}$ in spring barley in terms of the response of the varieties to the soil and weather conditions and suitability of the use of grain for malting are assessed within the production area (maize, sugar-beet, potato and mountain).

- agronomical data (time to heading, maturity, straw length, resistance to lodging).

- resistance to diseases (powdery mildew of barley (Blumeria graminis), leaf brown rust of barley (Puccinia hordei), net blotch of barley (Pyrenophora teres), scald of barley (Rhynchosporium secalis)).

- quality parameters of the grain (thousand grain weight and sievings over $2.0 \mathrm{~mm}$ ).

Table 2 Barley grain and malt analyses (2016-2018)

\begin{tabular}{|c|c|c|c|c|c|c|}
\hline Methods & & References & 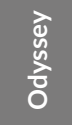 & 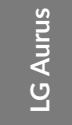 & $\begin{array}{l}\text { ठ․ } \\
\text { है } \\
\text { 宅 }\end{array}$ & 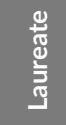 \\
\hline & & & $S$ & & & \\
\hline Protein content of barley (factor 6.25) d.m. & $\%$ & $\begin{array}{l}\text { EBC } 2010 \\
3.3 .1\end{array}$ & 10.2 & 10.4 & 10.4 & 10.3 \\
\hline Extract of malt (congress mash) d.m. & $\%$ & $\begin{array}{c}\text { EBC } 2010 \\
4.5\end{array}$ & 83.3 & 83.5 & 83.1 & 83.4 \\
\hline $\begin{array}{l}\text { Mash method according to Hartong and } \\
\text { Kretschmer VZ } 45^{\circ} \mathrm{C}\end{array}$ & $\%$ & $\begin{array}{l}\text { MEBAK } 2011 \\
\text { 4.1.4.11 }\end{array}$ & 44.2 & 46.6 & 46.8 & 47.4 \\
\hline Kolbach index & $\%$ & $\begin{array}{l}\text { EBC } 2010 \\
4.9 .1\end{array}$ & 48.9 & 49.5 & 50.7 & 49.9 \\
\hline Diastatic power & WK & $\begin{array}{c}\text { EBC } 2010 \\
4.12\end{array}$ & 319 & 318 & 368 & 321 \\
\hline Final attenuation of laboratory wort & $\%$ & $\begin{array}{c}\text { EBC } 2010 \\
4.11\end{array}$ & 82.0 & 82.1 & 82.2 & 81.5 \\
\hline Friability & $\%$ & $\begin{array}{c}\text { EBC } 2010 \\
4.15\end{array}$ & 92 & 93 & 91 & 92 \\
\hline $\begin{array}{l}\text { High molecular weight beta-glucan } \\
\text { content of malt, SFA }\end{array}$ & $\mathrm{mg} / \mathrm{l}$ & $\begin{array}{c}\text { EBC } 2010 \\
4.16 .2\end{array}$ & 123 & 137 & 109 & 152 \\
\hline Appearance (clarity) of wort & & $\begin{array}{l}\text { MEBAK } 2011 \\
3.1 .4 \cdot 2.6\end{array}$ & 1.00 & 1.08 & 1.00 & 1.25 \\
\hline Haze of wort $\left(90^{\circ}\right)$ & EBC & $\begin{array}{l}\text { EBC } 2010 \\
9.29\end{array}$ & 0.97 & 0.77 & 0.59 & 1.65 \\
\hline Haze of wort $\left(12^{\circ}\right)$ & EBC & $\begin{array}{l}\text { EBC } 2010 \\
9.29\end{array}$ & 1.39 & 1.03 & 0.64 & 1.80 \\
\hline
\end{tabular}


Table 3 Important agricultural properties (2016-2018)

\begin{tabular}{|c|c|c|c|c|c|c|c|}
\hline Variety & 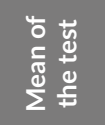 & 乲 웅 & 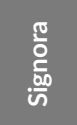 & $\begin{array}{l}\text { dू } \\
\frac{\tilde{n}}{0} \\
0\end{array}$ & 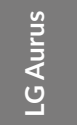 & $\begin{array}{l}\frac{8}{8} \\
\frac{8}{E} \\
\frac{E}{U}\end{array}$ & 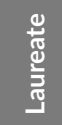 \\
\hline Grain yield & (t.ha-1) & $\mathbf{S}$ & S & $\mathrm{S}$ & & & \\
\hline maize production area & 6.93 & 6.95 & 6.71 & 6.86 & 6.79 & 6.76 & 7.32 \\
\hline sugar-beet production area & 6.92 & 6.75 & 6.46 & 6.76 & 7.20 & 6.95 & 7.18 \\
\hline potato and mountain production area & 7.44 & 7.46 & 6.99 & 7.85 & 7.69 & 7.46 & 7.84 \\
\hline \multicolumn{8}{|l|}{ Grain yield over $2.5 \mathrm{~mm}$} \\
\hline maize production area & 6.79 & 6.74 & 6.58 & 6.72 & 6.65 & 6.56 & 7.17 \\
\hline sugar-beet production area & 6.71 & 6.62 & 6.33 & 6.56 & 6.98 & 6.67 & 7.11 \\
\hline potato and mountain production area & 7.29 & 7.24 & 6.85 & 7.61 & 7.61 & 7.24 & 7.68 \\
\hline \multicolumn{8}{|c|}{ Agronomic data } \\
\hline straw length $(\mathrm{cm})$ & & 76 & 76 & 76 & 76 & 74 & 75 \\
\hline $\begin{array}{l}\text { earliness of ripening } \\
\text { (days compared to Odyssey) }\end{array}$ & & -2 & -1 & 0 & -2 & -2 & 0 \\
\hline standing power (lodging resistance) & & 8.1 & 8.1 & 6.8 & 7.2 & 6.7 & 7.3 \\
\hline \multicolumn{8}{|c|}{ Resistance to diseases } \\
\hline powdery mildew of barley (Blumeria graminis) & & 8.2 & 8.2 & 8.0 & 8.2 & 8.4 & 8.2 \\
\hline leaf brown rust of barley (Puccinia hordei) & & 6.4 & 6.5 & 5.6 & 6.0 & 5.8 & 6.3 \\
\hline net blotch of barley (Pyrenophora teres) & & 5.0 & 4.8 & 5.8 & 5.8 & 5.5 & 5.8 \\
\hline scald of barley (Rhynchosporium secalis) & & 7.9 & 8.2 & 8.0 & 7.9 & 7.8 & 8.2 \\
\hline \multicolumn{8}{|c|}{ Mechanical properties (grain quality) } \\
\hline 1000 grain weight $(\mathrm{g})$ & & 47.0 & 51.0 & 51.0 & 52.0 & 51.0 & 51.0 \\
\hline sieving fractions over $2.5 \mathrm{~mm}(\%)$ & & 97.3 & 98.1 & 97.7 & 98.2 & 97.0 & 98.3 \\
\hline $\mathrm{S}=$ standard varieties & & & & & & & \\
\hline
\end{tabular}

Point evaluation: 1 = fully lodging, fully attacked $\quad 9$ = non lodging, resistant to diseases Weight of 1000 grains relates to sieving fractions over $2.0 \mathrm{~mm}$ at $14 \%$ humidity.

\section{Results}

The present study evaluates the spring barley variety registered in the Slovak Republic after harvest 2018 according to the Malting Quality Index (Psota and Kosař, 2002).

The variety Chimbon, bred in Germany, gave malt with the optimal extract content (83.1\%) at the content of nitrogenous substances in non-malted grain of $10.4 \%$. Proteolytic modification was strong. The wort exhibited high values of soluble nitrogen $(861 \mathrm{mg} / \mathrm{l})$. Relative extract at $45^{\circ} \mathrm{C}$ characterizing the activity of namely cytolytic and proteolytic enzymes was at the optimal level (46.8\%). Amylolytic modification was high (diastatic power 368 WK units). Degradation of cell walls was at the low level of $91 \%$ and $\beta$-glucan content was on average around $109 \mathrm{mg} / \mathrm{l}$. The variety provided optimal wort quality, apparent final attenuation was on average around $82.2 \%$. The variety provided in all cases clear wort. Considering the achieved values of the studied technological parameters, the variety Chimbon has a malting quality with the point evaluation 8 (7.7).
The variety Chimbon was recorded in the Common catalogue of varieties of agricultural plant species in Poland (European Commission, 2019) and is admitted in Denmark and Austria.

Chimbon is a mid-early spring barley variety with the vegetation period of 107 days and the heading time of 65 days and is of mid-high type $(74 \mathrm{~cm})$ with a lower resistance to lodging. The variety has a good resistance to powdery mildew of barley. It is sensitive to net blotch of barley. Grain is big (TGW $51 \mathrm{~g}$ ) and the portion of sieving fractions is high (97\%).

During the tests in 2016 to 2018, the variety Chimbon achieved above average yields in the sugar-beet production area and potato and mountain production area. Compared to the average of the standard varieties in the Slovak Republic, the variety achieved the yield of 7.05 t/ha, i.e. $100.54 \%$.

The British variety Laureate provided malt rich in extract $(83.4 \%)$ at the optimal content of nitrogenous substances in non-malted grain $(10.3 \%)$. Proteolytic modification was strong (Kolbach index was around 49.9\%). 
The wort exhibited high values of soluble nitrogen at the level of $848 \mathrm{mg} / \mathrm{l}$. Relative extract at $45^{\circ} \mathrm{C}$ characterizing the activity of namely cytolytic and proteolytic enzymes was at the optimal level (47.4\%). Amylolytic modification was optimal (diastatic power 321 WK units). Cytolytic modification was above average to optimal. Degradation of cell walls was at the low level of $92 \%$ and $\beta$-glucan content was around $152 \mathrm{mg} / \mathrm{l}$. The variety provided wort with an optimal composition (apparent final attenuation was on average around $81.5 \%$ ). The variety provided in most cases clear wort. Considering the achieved values of the studied technological parameters, the variety Laureate has a very good malting quality with the point evaluation 8 (7.6).

The variety Laureate was recorded in the Common catalogue of varieties of agricultural plant species in Poland (European Commission, 2019) and is admitted in Germany, Estonia, France, Lithuania, Latvia, the Netherlands, Austria and the United Kingdom. In 2019 it was also registered in the Czech Republic (Psota et al. 2019). Laureate is a mid-late spring barley variety with the vegetation period of 108 days and the time of heading 67 days and is of a mid-high type $(75 \mathrm{~cm})$ with a medium resistance to lodging. The variety has a very good resistance to powdery mildew. It is sensitive to net blotch of barley. The grain is medium high (TGW $51 \mathrm{~g}$ ) and the portion of sieving fractions is very high (98\%).

In the course of the 2016 to 2018 tests, the variety Laureate achieved above average yields in all production areas. Compared to the average of standard varieties in the Slovak Republic, the variety achieved the yield of $7.45 \mathrm{t} / \mathrm{ha}$, i.e. $106.5 \%$ (in the maize production area $107 \%$, sugar-beet production area $106 \%$ and in the potato and mountain production area 107\%).

Malt of the Czech variety LG Aurus was rich in extract $(83.5 \%)$ at the optimal content of nitrogenous substances in non-malted grain (10.4\%). Proteolytic modification was strong. The wort exhibited high values of soluble nitrogen $(831 \mathrm{mg} / \mathrm{l})$. Relative extract at $45{ }^{\circ} \mathrm{C}$ characterizing the activity of namely cytolytic and proteolytic enzymes was at an optimal level (46.6\%). Amylolytic modification was high (diastatic power 318 WK units). Cytolytic modification was optimal. Degradation of cell walls was at the low level of $93 \%$ and $\beta$-glucan content moved around $137 \mathrm{mg} / \mathrm{l}$. The variety provided wort with an optimal composition (apparent final attenuation was on average around $82.1 \%$ ). The variety provided in most cases clear wort. Considering the achieved values of the technological parameters, the variety LG Aurus has a very good malting quality with the point evaluation 8 (8.0).

In 2019 it was registered in the Czech Republic (Psota et al. 2019).
LG Aurus is mid-early spring barley variety with the vegetation period of 108 days and heading time of 65 days. It is of a mid-high type $(76 \mathrm{~cm})$ with medium resistance to lodging. The variety has a good resistance to powdery mildew and is sensitive to net blotch of barley. It has a big grain (TGW $52 \mathrm{~g}$ ) and the yield of sieving fraction above $2.5 \mathrm{~mm}$ is very good (98\%). During the 2016 to 2018 tests, the variety LG Aurus achieved above average yields in the sugar-beet and potato and mountain production area. Compared to the average of the control varieties in the Slovak Republic, it achieved the yield of 7.23 t/ha, i.e. $103 \%$.

\section{Conclusion}

The study presents the results achieved by three varieties of spring barley which were registered in the Slovak Republic after the 2018 harvest. Quality was assessed based on the Malting Quality Index. The content of nitrogenous substances in the studied varieties of spring barley was at the optimal level (10.3 to $10.4 \%$ ). The varieties were rich in extract. More than $83 \%$ of extract was recorded in the varieties LG Aurus (83.5\%), Laureate (83.4\%) and Chimbon (83.1\%). Amylolytic and cytolytic modification in the studied varieties of spring barley was mostly at an optimal level. The spring barley varieties had high Kolbach Index (49.5-50.7\%). The quality of wort assessed by the apparent final attenuation in the studied varieties of spring barley was at the optimal level (over 82.0\%).

\section{Acknowledgements}

The study was funded from the institutional support of the Ministry of Agriculture CR (R01919), project of the Ministry of Education, Youth and Sports CR (LO1312), and the financial support of the owners of the barley varieties.

\section{References}

Act No. 597/2006 Coll. on the Competence of the State Administration in the Field of Registration of Varieties of Cultivated Plants and on the Introduction of Plant Propagating Material on the Market. In: Collection of Laws of the Slovak Republic. 20 October 2006.

Basařová, G., Čepička, J., Doležalová, A., Kahler, M., Kubíček, J., Poledníková, M., Voborský, J., 1992: Pivovarsko-sladařská analytika (1). Merkanta, Praha.

EBC Analysis committee, 2010: Analytica EBC, Barley: 3.2 Moisture Conten of Barley, 3.3.2 Total Nitrogen Content of Barley, Malt: 4.2 Moisture Content of Malt, 4.3.2 Total Nitrogen of Malt, 4.5.1 Extract of Malt, 4.9.1 Soluble Nitrogen of Malt, 4.12 Diastatic Power of Malt, 
4.15 Friability, 4.16.2 High Molecular Weight Beta-glucan Content of Malt and Malt Wort, Beer: 9.29 Haze in Beer: Calibration of Haze Meters. Fachverlag Hans Carl, Nüremberg. ISBN 978-3-418-00759-5. European Commission, 2019: Common catalogue of varieties of agricultural plant species - 37th complete edition. Official Journal of the European Union C 13, 11. 1.2019.

MEBAK, 2011: Raw material. 1 Barley: 1.5.3 Micromalting; Malz: 3.1.4.11 Maischmethode nach Hartong-Kretschmer VZ $45^{\circ} \mathrm{C}$. Mitteleuropäischen Brautechnischen Analysenkommission, Freising-Weihenstephan, Germany.
Psota, V., Kosař, K. (2002). Malting Quality Index. Kvasny prumysl, 48(6), 142-148. https://doi.org/10.18832/kp2002011

Psota, V., Dvořáčková, O., Nečas, M., Musilová, M. (2019). Barley varieties registered in the Czech Republic after harvest 2018. Kvasny prumysl, 65(3), 97-105. 